\title{
Türkiye'deki Uluslararası Film Festivalleri ve Uluslararası Eskişehir Film Festivali İzleyici Araştırması
}

\author{
International Film Festivals in Turkey and an Audience \\ Study of the Eskisehir International Film Festival
}

\section{Doç. Dr. Elif Gizem Uğurlu - Arş. Gör. Hakan Aşkan}

Başvuru Tarihi: 13.12.2017

Kabul Tarihi: 10.05 .2018

\section{Öz}

Film festivalleri filmleri, sanatçıyı, sinema emekçilerini ve izleyici kitlelerini buluşturan önemli organizasyonlardır. Festivallerde film seyretmeye gitmek, gündelik yaşamda sinemaya gitmekten farklıdır. Film festivalleri sadece sinema seyircisini bir araya getirmekle kalmaz, film sanatı ile ilgilenenlere de yeni kapılar aralar. Benzer şekilde yönetmen, oyuncu, senaryo yazarı gibi film üretiminde yer alan kişilerle ya da gösterim olanağ bulamamış filmlerin seyirci ile buluşmasına aracılık eder. Aynı içeriği seyredenlerin, filmlerin ardından konuşabilmesi için zemin hazırlar. Sinema tarihinin öne çıkan filmlerini sinema salonu atmosferinde seyredilebilmesine firsat verir. Elbette bir film festivalinin kişiye, topluma ve gerçekleştirildiği kente katkıları bu sayılanlarla sinırl değildir.

Bu araştırma ile 18 yıllık bir geçmişe sahip Uluslararası Eskişehir Film Festivalinin izleyici profilini tanımlanma çalışmaktadır. Bu amaçla 06-14 Mayıs 2016 tarihleri arasında rastlantısal örneklem alma tekniği ile bir anket çalı̧̧ması gerçekleştirilmiştir. Geçerli 250 anket, SPSS programı ile değerlendirilmiş ve araştırmacılarm festival organizasyonu deneyimleri ile harmanlanarak yorumlanmıştır. Ayrıca 2016 yılında Türkiye'deki film festivallerinin bir panoraması ortaya konulmuş ve film festivallerinin sinema sektörüne ve topluma olan etkilerini ortaya koymak amaciyla yapilan yaymlarm genel bir taraması da yapılmıştır.

Anahtar Kelimeler: Film Festivali, Eskişehir Film Festivali, İzleyici, Eskişehir

\begin{abstract}
Film festivals are highly important events and organizations that unite films, artists, cinema workers and the viewing audience. Attending a screening at a festival is different than going to the local cinema throughout our daily lives. Film festivals not only unite moviegoers, it also opens new doors for everyone interested in the art of film. Similarly, it facilitates the opportunity for the audience to meet directors, actors, screenwriters and everyone else participating in the production of films as well as the screening of films that previously had not been screened. It provides a platform of discussion for the viewers of common content. It allows prominent films in cinema history to be experienced within the atmosphere of a movie theatre. The contributions of film festivals to individuals, society, and the hosting city are not limited to these influences.
\end{abstract}

This study attempts to determine the audience profile of the Eskisehir International Film Festival, which has been a recurring event for 18 years. In this regard, a survey was conducted between 6-14 May 2016 using random sampling. The 250 valid questionnaires obtained were analysed with the SPSS statistical software and the results were combined with the researchers' festival organisation experiences for interpretation. Additionally, a portrayal of the film festivals in Turkey in the year 2016 was established along with a meta-analysis of the publications regarding the influence of film festivals on the film industry and on society.

Keywords: Film festival, Eskisehir Film Festival, Audience, Eskisehir

Doç. Dr. Elif Gizem Uğurlu, Anadolu Üniversitesi İletişim Bilimleri Fakültesi, egugurlu@anadolu.edu.tr Arş. Gör. Hakan Aşkan, İnönü Üniversitesi İletişim Fakültesi, hakan.askan@inonu.edu.tr 


\section{Giriş}

Kellner’a göre sinema, 20. yüzyılda ortaya çıkan kitlesel olarak üretilen ilk kültürel formlardan biridir (2004, s.205). Sinemanın ortaya çıkması her ne kadar tekniğin olanaklarının bir sonucu olsa da varlığını sürdürmesinin ön koşulu aslında seyirci kitlesidir. Auguste ve Louis Lumiere ${ }^{1}$ sadece Cinématographe's icat etmekle kalmamış, aynı zamanda 28 Aralık 1895 'te Paris'in Capucines Bulvarı'ndaki Grand Caféde ilk ticari kitlesel film gösterimini de gerçekleştirmişlerdir. Böylece aslında ilk kitlesel film gösteriminin yapıldığ tarih, aynı zamanda sinemanın başlangıcı olarak da kabul edilir (Özarslan, 2013, s.14). Dolayısıyla sinema ortaya çıkışını, 19. yüzyılda hareketli görüntünün teknik olarak kaydedilmesine borçlu iken varlığını devam ettirmesini ise seyirci kitlesine borçludur ve sinemanın ilk seyirci kitlesi de 19. yüzyıl kentlileridir.

Seyirci, sinema ile ilgili çalışmalarda hep var oldugu bilinen bir gerçek ve belirleyen olarak film-insan ilişkisi bağlamında kendini hatırlatan bir öğedir. Seyirci bir filmin "bakanı", "izleyeni", "göreni”dir ve bir filmin film olduğunun tanığıdır. Böyle olduğu için de bir film söz konusu olduğunda içeriğinden bağımsız olarak düşünülmesi gereken, seyircinin, o filmin tamamlayanı ve olmazsa olmaz parçası olma hali olmalıdır. Sinema temelde bir kent eğlencesi olarak hayatın içine girmeye başlamış ve kısa zamanda kent yaşamının bir vazgeçilmezi haline gelmiştir. Başka bir deyişle, sinema başlangıcı itibarıyla kent yaşamının olmazsa olmaz parçalarından biridir ve seyircisini kendi "ormanlarına" ve "dehlizlerine" çekip alma gücüne sahiptir (Kırel, 2012, s.14). Sinema-kent ilişkisi bağlamında Daney de benzer bir yaklaşım ortaya koymuştur. Daney, "Sinema kente ait bir olgudur. Kentten önce var olmamıştır, kentten daha uzun süre yaşamayacaktır. Sinema ve kent arasındaki ilişki, ortak bir noktadan öte, ortak bir kaderdir" (akt. Öztürk, 2003, s.59) der.

Jarvie (1993, s.23), sinemanın tam anlamıyla bir kitle sanatı olmasını, [sinemanın] yalnızca seyirci kitlesine hitap etmesinden dolayı değil, kişinin sürekli devam eden gösterinin karanlığında kaybolmuş olmasına bağlar. Ona göre (1993, s.23) sinemaya gitmenin sosyal bir unsuru vardır. [Sinemaya gitmek] tam olarak

1 Ayrıca Lois Lumiere 1939'da Cannes'da başkanlığını kendisinin yapacağı bir festival de düzenlemeyi planlamıştı ancak savaştan sonra -1946'da- gerçekleşebildi (Cannes Film Festivali, 2017). yalnız yapılan bir faaliyet de değildir. Aileyle, okulla, arkadaş gruplarıyla ve sevgiliyle gidilebilir. Bu nedenle sinemaya gitmenin sosyalleştiren bir niteliği de vardır. Benzer şekilde Turner da sinemanın "sosyal birleştirici/ bütünselleştirici (social integrator)" (akt. Kırel, 2012, s.30) bir rolü olduğunu vurgular. Sinemaya gitmek sadece film seyretmek için yapılan bir eylem değildir. İnsanlar daha çok bir grup aktivitesi olarak sinemaya giderler. Hauser ise sinemanın resim, heykel gibi plastik sanatlardan ve klasik müzik gibi üst kültür ürünlerinden farklı olduğunu öne sürer ve sinemanın seyirci kitlelerini sinema salonlarında buluşturan nedeni şöyle açıklar: "Bu insanlar arasındaki tek bağ sinema salonlarını doldurmaları ve yeniden kişisel biçim kazanamamış birer birey olarak, toplumun içine tekrar katılmalarıdır. Sinema seyircisinin bu karışık, mafsallanması eksik, şekilsiz bir kitle meydana getirmesine karşın tek ortak yanı, herhangi bir sinıf veya kültür çevresine ait olmamasidir" (1984, s.420).

Sinemanın sosyal birleştirici olmasının yanı sıra da sermayenin denetimi altındaki bir sektör olduğu da hatırlamalıdır. Özellikle zincir sinema salonlarında aynı anda onlarca, yüzlerce kopya ile vizyona giren filmler, bir pazarın ürünüdür. Arkasında büyük bir finans desteği olmadan bir filmi gerçekleştirip, kopyalarını çoğaltıp dağıtım ağı olmadan pazarlayabilmek mümkün görünmemektedir. "İzleyici bunu istiyor" yaklaşımı ile üretilen filmlerden oluşan tekelin kırılabileceği organizasyonlardan birinin de film festivalleri olduğu açıktır. Ayrıca film festivalleri izleyicisini de şekillendiren, eğiten, yetiştiren organizasyonlardır. Erkılıç, 2000'li yılların, "bir yandan popüler filmler aracılığıyla televizyonla yetişen genç kitleyi sinema salonlarına kazandırırken, diğer yandan festivaller, kültür merkezleri, ev sinemaları sinefillerin ${ }^{2}$ buluşma yeri” (2009, s.152) olduğunu ifade eder.

Seyir eyleminin yukarıda da vurgulanan sosyal niteliğinin en yoğun şekilde gerçekleştiği alanların başında şüphesiz ki film festivalleri gelmektedir. Ulusal ya da uluslararası film festivalleri programlarında sinema tarihine geçmiş ve geçecek filmleri bulundurabilirler. Festival filmleri sanatsal filmleri, dünya sinemalarını ve alternatif filmleri içerdiği için festivaller dışında bu filmlere popüler film gösterimleri yapan sinemalarda ulaşmak oldukça zordur. Seyircinin bu filmlere

2 Sinefil; sinemaseverlik, sinema dostu olmak veya sinema tutkunu olmak anlamında kullanılır. 
festivaller dışında erişememesi, filmlerin durumuyla karşılıklıdır. Festivaller olmasa bu filmler uluslararas1 arenada gösterime girme şansını elde edemezler (Öcal, 2013, s.4). Bu nedenle uluslararası film festivallerinde "[...] seyircinin tanımının artık değiştiğini ve giderek uluslararası ölçekte bir küresel seyirci haline geldiğini rahatlıkla söyleyebiliriz" (Kırel, 2006: 59). Festivaller ve festival izleyicisi arasında özel bir bağ olduğu söylenebilir. Giritlioğlu ve Avcıkurt (2010, s.85)'a göre; Türkiye'de çok sayıda festival ve etkinlik bulunmasına rağmen bu etkinliklerin çok az bir kısmı uluslararası düzeydedir. Film festivalleri uluslararası katılımlı gerçekleştirilmeye uygun, sinema kültürünü yaymak açısından da önemli faaliyetlerdir (Uğurlu ve Uğurlu, 2011, s.259). Festivallerin etkin olabilmesinde festival faaliyetlerinin önceden planlaması, festival programının içeriği, paydaşların desteği, izleyici ve katılımcıların memnuniyeti önemlidir.

"Bir festival programının kalitesini faaliyet çeşitliliği, finansal açıdan sponsor desteği, eşzamanlılık, tecrübe ederek kazanım sağlaması, festivalin esnekliği ve geleneksel kültür ve turizm faaliyetleri ile bağlantısı belirlemektedir. Ayrıca bir festival programının temel amacı; festivalin devamlılığını, tutunmasını ve finansal açıdan sürdürülebilirliğini sağlamak olmalıdır” (Yan vd. 2012, s.655 - 658'den akt. Gül vd. 2013, s.215).

Film Yön Derneği Başkanı Çelik (2014), Boğaziçi Sinema Derneğìnin düzenlediği "Film Festivalleri ve Türkiye'de Sinemanın Geleceği” konulu forumda festivallerin; "sinemada sadece film göstermenin ötesine geçip o ülke sinemasının, sanatının dünya ile entegrasyonundan tutun kendi ülkesindeki sinemasal sorunların dile getirildiği, çözüme yönelik yapıların masaya yatırıldığı birer merkez halini” aldığının altını çizmiştir. Aynı forumda sinema yazarı Özyurt (2014) ise Türkiye'de İstanbul Film Festivali’ni örnek göstererek film festivalinin bir ekol ve okul olma hali olduğunu ve oradan birçok yönetmen yetiştiği gibi birçok sinema yazarının da yetiştiğini, dolayısıyla festivallerin sinema ve seyirciye ciddi katkıları olduğunu ifade eder.

$\mathrm{Bu}$ festivallere katılan seyirci profili ile film tercihlerini öğrenmek özellikle sinema endüstrisi açısından son derece önemlidir. Güçhan’ın (1993, s.56) da vurguladığı üzere "sinemanın seyircisine olan gereksinimi, onu tanımaya, eğilim ve isteklerini öğrenmeye yöneltmiștir. Filmler birer 'ürün’ olduklarına göre, onları tüketenler için araştırma yapmanın önemi olduğu açıktır." Bu çalışma on sekiz yıldır devam eden Uluslararası Eskişehir Film Festivali seyircisinin profilini tanımlamak ve onların film tercihlerini ve 2016 yllına ait Türkiye'deki film festivallerinin bir panoramasını ortaya koymaktadır. Türkiye'de film festivalleri ve bu festivallerden birinin izleyici profilini tanımlamak için yapılmış ender çalışmalardan biri olması çalışmanın önemini arttırmaktır.

\section{Festival Kavramı ve Uluslararası Film Festivalleri}

Tarihi önceden belirlenmiş, belirli bir sürede ve isimde düzenlenen, gelenekselleşmiş, toplum belleğinde yer edinmiş, bir yörenin simgesi haline gelmiş, sürekliliği sağlanmış etkinlikler olarak tanımlanan (Gürsoy vd., 2004, s.171; McKercher, 2006, s.56; Küçük, 2013, s.347; Pios vd. 2014, s.119) festival kavramı "dünyada ve Türkiye'de kültürel ve sanatsal faaliyetler, fuarlar, alışveriş, sergiler, spor olayları, düzenlenen etkinlikler olarak karşımıza çıkmaktadır” (Küçük, 2013, s.14). Tanımdan da anlaşılabileceği gibi, "birçok kentin kendine özgü festivalleri olmakla birlikte konusu kültür ya da spor gibi alanlar olabilmektedir" (Özdemir, 2008, s.33). Ancak festivallerin farklı işlevleri de bulunmaktadır. Houghton (2001, s.39) festivallerin işlevlerini turizm, eğlence, eğitim, sosyal etkileşim, iş, ticaret ve ilham kaynağı olarak sıralamaktadır. Litvin ve Fetter (2006, s.44) da festivallerin bölgeye gelen ziyaretçi sayısını arttırdığını, ekonomik getiri sağladığını, yerel halkın gururunu arttırarak yörenin imajını geliştirdiğini ifade ederler. Küçük (2013, s.14), yerel kalkınma kavramını yerele özgü kaynakların kamu ve özel sektör iş birliği ile yörede planlı ve programlı uygulamalar sonucu mevcut durumun geliştirilerek belirlenen hedeflere ulaşılması olarak açıklarken bir yerelin kaynakları arasında doğal kaynaklar, iklim, çevre peyzaj, tarihi alanlar ticaret, spor alanlarının yanı sıra sosyo-kültürel kaynaklar, kültür sanat ve festivallerin zenginlik olduğunu ifade etmektedir. Bu bağlamda film festivallerin yerel kalkınmaya da destek olabileceği anlaşılmaktadır. Elbette film festivalleri aynı zamanda bir çeşit turizm etkinliğidir. Yıllarca sürdürülebilen, adını duyurma şansına sahip olabilen büyük organizasyonlar önce yerel ardından da ulusal ekonomik gelire katkıda bulunma potansiyeline sahiptir. Festivaller yerel ekonomiyi çeşitlendi- 
rip yerel halk için iş olanağ yaratabilen bir kaynak, yerel ürünlerin üretimi ve yeni turizm tesislerinin artması için teşvik, döviz sağlayabilen bir etkinlik, yaşam standartlarının iyileşmesi için fırsat, yerel vergi gelirleri yaratabilecek, çalışanların yeni beceriler geliştirmesini sağlayabileceği bir alan olarak düşünülür (Eagles vd., 2002, s.24). Çulha (2008, s.1831) festivallerin "ülkenin uluslararası piyasada tanınmasına neden olması"nın, onun en önemli niteliği olduğunun altını çizmiştir. Festivalleri izleyici sayılarını dikkate alarak beş sınıfa ayırır; yöresel etkinlikler, küçük bölgesel etkinlikler, önemli bölgesel etkinlikler, ulusal etkinlikler, uluslararası büyük etkinlikler.

Yöresel etkinlikleri; çeşitli müzik, tiyatro gruplarının gösterisi; resim sergileri, yöresel festivaller olarak açılar ve "karpuz, kiraz festivali, deve güreşi, yağlı güreş organizasyonları, panayırlar vb." olarak örneklendirir. Küçük bölgesel etkinlikler; çeşitli ticaret ve sanayi fuarları ve özel mesleki fuarlar ve sergiler olarak açıklanırken, Uluslararası İzmir Fuarı, Selanik Fuarı vb. küçük bölgesel etkinliklere örnek olarak sunulur. Mesleki fuarlara da banyo fuarı, turizm fuarı, kuyumculuk fuarı vb. örneklerini verir. Önemli bölgesel etkinlikleri; İstanbul Müzik Festivali vb. olarak açılayan Çulha, ulusal etkinlikleri Rio Karnavalı, Cannes Film Festivali vb. örneği üzerinden tanımlar. Uluslararası büyük etkinlikler için ise "Dünya $\mathrm{Ku}$ pası, Olimpiyat Oyunları vb.” açıklamasını yapar. Bu sınıflandırmalardan yola çıkarak bir etkinliğin ya da festivalin başına" uluslararası" kelimesinin konması ile ilgili bir sinırlandırma olmadığından yöresel etkinliklerde bile karşılaşılan bu ifadenin katılım sayısı beklentisinden ziyade farklı uluslardan ziyaretçi katılımını ifade ettiği düşünülebilir. Ulusal ya da uluslararası film festivalleri, bulundukları kent ve ülkeler için ayrıcalıklı kültürel, ekonomik değer ve kazanım oluşturur ayrıca küresel bir ağın da parçasıdırlar. Festivallerin sosyo-ekonomik bir değeri vardır ve düzenlendikleri yere katma değer sağlamaktadırlar. $\mathrm{Bu}$ bağlamda tarihi değerler, gıda ürünleri ya da geleneklerin yaşatılması festivalleri gibi kültürel, sanatsal festivallerin de düzenlenmesi turistik bir strateji haline gelmiştir (Yıldız ve Polat, 2016, s.40).

Küresel film festival ağının ana merkezlerini büyük uluslararası film festivalleri oluşturur. En prestijli ve dünyaca ünlü büyük film festivallerinin birçoğu Avrupa'dadır. Venedik (1932'den beri), Melbourne (1951'den beri), Cannes (1939'da ilki düzenlenmiş, 1952'den beri düzenli), New York (1963'ten beri), Toronto (1976, TIFF), Berlin (1978'den beri düzenli, Berlinale) ve Sundance (1985'ten beri) gibi büyük festivaller ${ }^{3}$ festival ağının en önemlileri olarak kabul edilirler (Uğurlu ve Uğurlu, 2011, s.261-262). Bu festivaller aynı zamanda dünya sinemalarının görünür kılınmalarına giden yolda önemli "geçit"lerdir. Bu geçitler dünya sinemasının kültürel meşruluğunu temin eder (Marijke'den akt. Öcal, 2013, s.4). Uluslararası film festivalleri Batı-dışı ulusal sinemalara yapım şansı tanımak adına destek sağlarlar. Festivaller 1980'lerle ortak yapımlara yöneltecek pazarları açmışlar ve bu on yılın sonlarından itibaren de festival fonlarını 'gelişmekte olan ülke' sinemalarına sunmuşlardır. Yerel yapımcılar, senaryo geliştirme aşamasından başlayarak yapımın çeşitli merhalelerinde fonlardan yararlanabilmektedir. Ekonomik gelişmişliğini yani zenginliğini bağışlayarak paylaşan Batı, teknolojisini, bilgisini, demokrasisini fonlarla destekledikleri film yapımcılarına, kültürel ve sanatsal üretimlerine açmaktadır. Senaryo geliştirme aşamasından başlayarak alınabilen desteklerin sadece filmlerin üretilmesine fayda sağlamakla kalmamaktadır. Fon alan filmler özellikle fon sağlayan kurumun ülkesine bağlı ortak yapımlara yöneltilmekte, çeşitli yapım aşamalarında ekip, ekipmanla filmin yapımına müdahil olunmaktadır. Ulusal filmlere sağlanan bu desteklerin organize destek projeleri yürüten kaynak sahiplerine de getirisi olması normal olarak değerlendirilebilir. Ortaya çıkan anlatıların yenilikçi, deneysel, kültürel farklılıkları Hubert Bals'in deyimiyle "sinematografinin geleceğinin Avrupa ya da ABD'de değil de daha ziyade az bilinen film kültürlerinde" olması, pazara ve kültür endüstrisine katkı sağlamaktadır. Üretim sürecinin çeşitli aşamalarında pay alınmasını sağlayan (görüntü, ses, efekt, kurgu vb. yapım ve yapım sonrasında) Batı'nın insan iş gücünün ve teknolojilerinin de kullanılması şartı pazara katkı sağlamaktadır (Öcal, 2013, s.5).

\section{Festivallerle Illgili Akademik Çalışmalar ve Türkiye'deki Uluslararası Film Festivalleri}

Getz (2010, s.1-5) "The Nature and Scope of Festival Studies" adlı çalışmasında İngilizce yazılmış hakemli dergilerde yaptığ 1 tarama araştırması ile festivallerle ilgili 423 makale bulunduğunu ifade etmiştir. Bunla-

3 Tarihçeleri ile ayrıntılı ilgili bilgi festivallerin resmî web sitelerinin tarihçe bölümünden alınabilir. 
r1 festivallerin toplum ve kültüre olan etkisi, festival turizmi ve festival yönetimi başlıkları altında sınıflandırmıștır. Getz'in çalışmasından yola çıkarak taranan 423 makalede doğrudan film festivali ile ilgili 6 çalışma olduğu görülmüștür. Gamson (1996), Frohlick (2005), Evans (2007), Kim ve Hong (2007), Frost (2008)'un çalışmalarında film festivalleri dolaylı olarak ele alınmıştır. Grunwell ve Ha (2008)'nın çalışması ise film festivallerinin başarısı ile ilgili ampirik bir çalışmadır. Öte yandan film festivalleri araştırma sosyal medya ağının (www.filmfestivalresearch.org) 2015 yılında listelediği yukarda sayılanların dışında çoğu 2009 yılından sonra yapılmış 30 İngilizce yayın bulunmaktadır. Bu çalışmalar içinde bulunan Wallin vd. (2013)'nin çalışması ise festivalin sürdürülebilirliğini konu edinmekte, Kanada’da küçük bir kent festivalini örneklem olarak incelemektedir. Bütün bu araștırmalar içinde, Türkiye'deki film festivalleri ile ilgili yapılmış İngilizce yayından bahsedilmediği görülmüştür.

Türkiyede yapılan akademik çalışmalarda festivaller konusu çeșitli anahtar kelimelerle ve çeșitli veri tabanlarında araştırıldığında; Giritlioğlu ve Avcıkurt (2010); Giritlioğlu vd. (2015); gibi araștırmacıların çalışmalarına bakarak halk oyunları (Uzunkaya, 2009); yöresel mutfak kültürü (Şengül ve Genç, 2016) bağlamında turizm kapsamında, halkla ilişkiler araştırmalarında (Ferah ve Gülay, 2015) veya festival katılımcılarının algılarına yönelik (Yıldız ve Polat, 2016) olarak ele alındığ 1 anlaşılmıştır. Yıldız ve Polat'in yaptığ Eskişehir'de düzenlenen festivallerin etkinliklerine yönelik algıların dağılımı çalışmasına göre; festivaller yerel halk için eğlence firsatlarını, kentte bulunan ziyaretçi sayısını, yerel halkın kentleriyle duydukları gururu arttırmış, yerel halka bulunduğu toplum d1şından yeni insanlarla tanışma fırsatı sağlamış, kentin ünü artmıştır. Öte yandan olumsuz etkilerini de saptamışlardır. Ortalamaları dikkate alarak daha çok olumsuz algılanan ifadelere göre; festivaller süresince toplumdaki suç oranı artmış, aşırı kalabalık yerel yönetimlerin hizmetlerini aksatmış, festival süresince çevre kirliliği ve gürültü düzeyi $\operatorname{artmıştır~(2016,~s.47).~}$ Bu ifadelerin film festivali dışındaki diğer festivalleri de kapsadığı hatırlanmalıdır. Fida Film’in 1994 yılında yaptığı araştırma İstanbul Film Festivali’nin izleyici profilini ortaya koymaktadır (Erkılıç, 2009, s.153). Altıntaşıın (2009) İngilizce basılmış kitap içinde yer alan makalesi Antalya Film Festivali'nin yerel halka etkisini ele almaktadır. Uğurlu ve Uğurlu’nun (2011) makalesi Uluslararası Eskişehir Film Festivali izleyici araştırması üzerine yoğunlaşmakta, Polat vd.nin (2013) çalışması kent kimliği kapsamında Altın Safran Film Festivalini konu edinmektedir. Elkatmışın (2015) derlediği "Film Festivalleri ve Türkiye'de Sinemanın Geleceği” adlı çalışma ise bu konuda yapılan forumun deşifresidir. YÖK Tez Merkezi tarandığında "festival" anahtar kelimesine ilişkin 74 adet tez bulunmaktadır. Ancak bunlardan 5 tanesi (Ekin, 2011; Akari, 2016; Öcal, 2013; Batık, 2008; Yıldırım, 1990) film festivalleri ile ilgili olmakla birlikte sadece biri (Akari, 2016) festival özelinde, Gezici Filmmor Kadın Filmleri Festivali’ni kapsayan bir çalışmadır. Görüldüğü gibi Türkiye'de ve dünyada film festivalleri üzerine yapılan çalışma sayısı oldukça sınırlıdır.

\section{Türkiye'deki Ulusal ve Uluslararası Film Festivalleri}

Uluslararası Film Yapımcıları Birliği Federasyonu (FIAPF; International Federation of Film Producers Associations) uluslararası film festivali düzenlenmesinden de sorumludur. Federasyonu 27 ülkeden 30 üye dernek oluşturmaktadır. FIAPF resmi olarak tanıdığ film festivallerini dört sinıfta toplamaktadır; yarışmalı film festivalleri, özel alan yarışmalı film festivalleri, yarışmalı olmayan film festivalleri, belgesel ve kısa film festivalleri. Uluslararası Antalya Altın Portakal Film Festivali ve Uluslararası İstanbul Film Festivali; özel alan yarışmalı film festivalleri içinde yer almaktadır (FIAPF, 2017). Bu organizasyona Türkiye'den iki uluslararası festivalin akredite olduğu görülmüştür. Türk Akreditasyon Kurumu’na göre akreditasyon; "uygunluk değerlendirme kuruluşlarınca gerçekleştirilen çalışmalar sonucunda düzenledikleri uygunluk teyit belgelerinin güvenilirliğini ve geçerliliğini desteklemek amaciyla oluşturulmuş bir kalite altyapısı" olarak tanımlanmaktadır (TÜRKAK, 2017). Belirli aralıklarla da yenilenmesi gereken akreditasyon, uluslararası ölçütler dünya genelinde kabul gören gereklilikler esas alınarak gerçekleştirilmektedir. Ancak akredite olmak etkin ve sürdürülebilir bir festival olma garantisi ya da yeterliliği değildir. Türkiye’de uluslararası film festivalleri ulusal sinemalara maddi ya da teknik anlamada yardım edebilecek yeterli kaynağa sahip değildir. Hatta bir kısmı T.C. Kültür ve Turizm Bakanlığı Sinema 
Genel Müdürlüğ̈̈ ${ }^{4}$ fonundan destek almaktadır. Sinema eserlerinin seyircilere ulaşmasını sağlamak ve sanat bilincini yükseltmek gibi bir görevi olduğundan 2011 yılından beri bazı festivallere maddi katkıda bulunmaktadır.

T.C. Kültür ve Turizm Bakanlığ 1 Sinema Genel Müdürlüğü internet sayfasında Türkiye'de 11 film uluslararası film festivali olduğunu belirtmiștir. Bunlar; Ankara Uluslararası Film Festivali, Uluslararası Antalya Altın Portakal Film Festivali (2015 yılından itibaren Uluslararası Antalya Film Festivali adıyla düzenlenmeye başladı), Uluslararası İstanbul Film Festivali, Randevu İstanbul Film Festivali, Gezici Festival, !f İstanbul Uluslararası Bağımsız Filmler Festivali, Bursa İpekyolu Film Festivali, Uçan Süpürge Uluslararası Kadın Filmleri Festivali, Malatya Uluslararası Film Festivali, Uluslararası Gezici Filmmor Kadın Filmleri Festivali ve SineMASAL Açı Hava Sinema Festivalidir. Bursa İpekyolu Film Festivali, 2006-2009 yılları arasında sadece üç kez düzenlenmiștir. Malatya Uluslararası Film Festivali (MUFF) de 2016 yılında gerçekleştirilememiştir. Festival Komitesi, 04-10 Kasım 2016 tarihleri arasında 7.sini düzenleyeceğini duyurduğu festivalin "Türkiye’de yaşanan olağanüstü durumlar ve festivalin kurumsal bir yapıya dönüştürülmemesinden dolayı" ileri bir tarihe ertelenmesinin kararlaştırıldığını duyurmuştur (malatya.gov.tr, 2017). Gezici Festival, SineMASAL Açık Hava Sinema Festivali ise uluslararası ibaresi taşımamaktadır. Öte yandan Uluslararası Adana (Altın Koza) Film Festivali, Uluslararası Kar Film Festivali ve Uluslararası Eskişehir Film Festivali gibi on yıldan uzun süredir gerçekleştirilen film festivallerinin bu liste içinde yer almadığı görülmüştür.

Bu çalışma için 2016 yılında Türkiye'de düzenlenmiş olan film festivallerine ulaşmak amaciyla İnternette çeşitli anahtar kelimeler girilerek bir araştırma gerçekleştirilmiştir. Bu araştırma sonucunda (kısa film

4 Sinema Genel Müdürlüğ̈̈; 02.11. 2011 tarih ve 622 sayılı Kanun Hükmünde Kararname ile Kültür ve Turizm Bakanlı̆̆ı’nın bir ana hizmet birimidir. "Görevi; Ulusal sinema eserlerinin yaygın olarak izleyiciye ulaştııılmasını sağlamak ve sanat bilincini yükseltmek yönünde politikalar üreterek, bu amaca hizmet eden projeleri desteklemek, nitelikli eser üretimini teșvik etmek, kültür mirasımızın gelecek kuşaklara aktarılmasını sağlamak ve uluslararası boyutta Türk sinemasının yerini ve rolünü güçlendirmek." https://www.turkiye.gov.tr/sinema-genel-mudurlugu, son erişim. 18.01. 2017 festivali, gezici film festivali, belgesel festivali, düzenleyen kurum/kuruluş vb. konularda ayrım yapılmaksızın) ulaşılan film festivali sayısı 81'dir. Bütün film festivaller listelendikten sonra bunlar bazı başlıklar altında toplanarak sınıflandırıldığında belgesel, gezici, kısa ve üniversiteler tarafından düzenlenen festivaller de dahil toplam 44 uluslararası film festivali olduğu sonucuna varılmıştır. Ulusal film festivali sayısı ise (kısa film festivalleri ve üniversiteler tarafından düzenlenenler de dahil olmak üzere) toplam 37'dir.

Türkiyede 2016 yllında düzenlenen ulusal film festivali (üniversiteler tarafından organize edilen ulusal festivaller hariç) sayısı ise 27 'dir. Bu festivallerden 3’ü (Akbank Kısa Film Festivali, Karaköy Kısa Film Günleri ve Manastre Kısa Film Günleri) kısa film festivalidir. Tablo 1.de yer alan festivallerden Gezici Festival, 22 ylllık bir geçmişe sahiptir. 10 ylldan daha uzun süre devam eden diğer üç festival ise Akbank Kısa Film Festivali, Dağ Filmleri Festivali ve Köyceğiz Kaunos Altın Aslan Türk Filmleri Festivalidir. 2016 yllında ilk kez düzenlenen ulusal nitelikli film festival sayısı ise 8'dir. Bu festivaller; Adalet ve Direniş Filmleri Festivali, Bursa Fantastik Filmler Festivali, Çalı Köy Filmleri Festivali, Çocukça Film Festivali, Göbeklitepe Film Festivali, Kuir Belgesel Gösterimleri, Maltepe Belediyesi Sinema Belgesel Film Şenliği ve Manastre Kısa Film Günleri’dir.

Türkiye'de 2016 yılında üniversiteler tarafından düzenlenen ulusal film festivali sayısı 10'dur (Tablo 3.). 2016 yılında Marmara İletişim Kısa Film Festivali, Marmara Üniversitesi tarafından 13. kez düzenlenirken; Palto Film Günleri ise Anadolu Üniversitesi tarafından 10. kez düzenlenmiş̧ir. Afyon Kocatepe Üniversitesi tarafından düzenlenen Kocatepe Öğrenci Filmleri Festivali ise ilk kez 2016 yllında izleyicisiyle buluşmuştur.

Üniversitelerin düzenledikleri dışında kalan yukarıdaki festivallerden 8'i kısa film 4'ü belgesel film festivalidir. 16 'sı on yıl veya çok daha uzun süredir düzenlenmeye devam etmektedir. Buna karşın 22 festival on yıldan kısa bir süredir düzenlemektedir bunlardan 8'i 2016 yllında Türkiye'de ilk kez düzenlenen uluslararası film festivalidir. Türkiye'de üniversiteler tarafından da uluslararası film festivalleri düzenlenmektedir. 
Tablo 1. Ulusal Film Festivalleri

\begin{tabular}{|l|l|}
\hline Yll & \multicolumn{1}{|c|}{\begin{tabular}{c}
\multicolumn{1}{c|}{ Türkiye'deki Ulusal Film Festivalleri } \\
(Ünersiteler tarafından düzenleyen)
\end{tabular}} \\
\hline 22. & Gezici Festival \\
\hline 12. & Akbank Kısa Film Festivali \\
\hline 11. & Dağ Filmleri Festivali \\
\hline 11. & Köyceğiz Kaunos Altın Aslan Türk Filmleri Festivali \\
\hline 9. & Documentarıst İstanbul Belgesel Günleri \\
\hline 9. & Sürdürülebilir Yaşam Film Festivali \\
\hline 8. & Hangi İnsan Hakları Film Festivali \\
\hline 7. & Balıkesir Sinema Günleri \\
\hline 6. & Bodrum Türk Filmleri Haftası \\
\hline 5. & Bursa Kadın Filmleri Festivali \\
\hline 5. & Fantasturka Türk İşi Fantastik Film Festivali \\
\hline 5. & Pembe Hayat Kuirfest \\
\hline 4. & Ankara Engelsiz Filmler Festivali \\
\hline 4. & Filmamed Belgesel Film Festivali \\
\hline 3. & Axtamara Van Film Günleri \\
\hline 3. & Deniz Filmleri Festivali \\
\hline 3. & Sinema Dans Ankara-Dans Filmleri Festivali \\
\hline 2. & Bursa Engelsiz Film Festivali \\
\hline 2. & Karaköy Kısa Film Günleri \\
\hline 1. & Adalet ve Direniş Filmleri Festivali \\
\hline 1. & Bursa Fantastik Filmler Festivali \\
\hline 1. & Çalı Köy Filmleri Festivali \\
\hline 1. & Cocukça Film Festivali \\
\hline 1. & Göbeklitepe Film Festivali \\
\hline 1. & Kuir Belgesel Gösterimleri \\
\hline 1. & Maltepe Belediyesi Sinema Belgesel Film Şenliği \\
\hline 1. & Manastre Kısa Film Günleri \\
\hline
\end{tabular}

Tablo 2. Üniversiteler Tarafından Düzenlenen Ulusal Film Festivalleri

\begin{tabular}{|l|l|l|}
\hline Yıl & Üniversiteler Tarafından Düzenlenen Ulusal Film Festivalleri & Üniversite \\
\hline 13. & Marmara İletişim Kısa Film Festivali & Marmara \\
\hline 10. & Palto Film Günleri & Anadolu \\
\hline 9. & Ege Belgesel Film Günleri & Ege \\
\hline 9. & Sinepark Kısa Tür Filmi Festivali & Hacettepe \\
\hline 6. & Hacettepe Üniversitesi Belgesel Haftası & Hacettepe \\
\hline 5. & Bizim Filmler Festivali & İstanbul \\
\hline 3. & Uşak Kanatlı Denizatı Kısa Film Festivali & Uşak \\
\hline 2. & Akdeniz Belgesel Film Günleri & Akdeniz \\
\hline 2. & Altın Baklava Film Festivali & Hasan Kalyoncu \\
\hline 1. & Kocatepe Öğrenci Filmleri Festivali & Afyon \\
\hline
\end{tabular}


Tablo 3. Uluslararası Film Festivalleri

\begin{tabular}{|l|l|}
\hline Yıl & \multicolumn{1}{|c|}{ Uluslararası Film Festivalleri } \\
\hline 53. & Uluslararası Antalya Film Festivali \\
\hline 35. & Uluslararası İstanbul Film Festivali \\
\hline 28. & Uluslararası İstanbul Kısa Film Festivali \\
\hline 27. & Uluslararası Ankara Film Festivali \\
\hline 23. & Uluslararası Adana Altın Koza Film Festivali \\
\hline 19. & Uluslararası Randevu İstanbul Film Festivali \\
\hline 19. & Uluslararası Uçan Süpürge Kadın Filmleri Festivali \\
\hline 17. & Uluslararası İzmir Kısa Film Festivali \\
\hline 17. & Uluslararası Safranbolu Belgesel Film Festivali \\
\hline 15. & Uluslararası Gezici Filmmor Kadın Filmleri Festivali \\
\hline 15. & Uluslararası !F İstanbul Bağımsız Filmler Festivali \\
\hline 14. & Uluslararası İstanbul Çevre Kısa Film Festivali \\
\hline 11. & Uluslararası Crossroads Kısa Film Festivali \\
\hline 11. & Uluslararası İçi Filmleri Festivali \\
\hline 10. & Uluslararası İkinci El Kı Fisa Film Festivali \\
\hline 10. & Uluslararası İstanbul Mimarlık ve Kent Filmleri Festivali \\
\hline 9. & Uluslararası Çayda Çıra Film ve Sanat Festivali \\
\hline 7. & Uluslararası İnsan Hakları Belgesel Film Günleri \\
\hline 7. & Uluslararası Barikat Film Festivali \\
\hline 6. & Uluslararası Gençlik Filmleri Festivali \\
\hline 5. & Uluslararası Çocuk Hakları Kısa Film Festivali \\
\hline 5. & Uluslararası Van Gölü Film Festivali \\
\hline 5. & Uluslararası Tekirdağ Fotoğraf ve Belgesel Festivali \\
\hline 4. & Uluslararası Altın Çınar Film Festivali \\
\hline 4. & Uluslararası Canlandıranlar Festivali \\
\hline 4. & Uluslararası Boğaziçi Film Festivali \\
\hline 3. & Uluslararası Bozcaada Ekolojik Belgesel Festivali \\
\hline 2. & Uluslararası Edirne Film Festivali \\
\hline 2. & Uluslararası Marmaris Kısa Film Festivali \\
\hline 1. & Uluslararası Antalya Film Günleri \\
\hline 1. & Coğrafyalararası Anarşist Kısa Film Festivali \\
\hline 1. & Uluslararası İstanbul Turizm Filmleri Festivali \\
\hline 1. & Uluslararası Kan Film Festivali \\
\hline 1. & Türk Dünyası Belgesel Film Festivali \\
\hline 1. & Uluslararası Alanya Kristal Kale Film Festivali \\
\hline 1. & Uluslararası Eskişehir Kısa Film Festivali \\
\hline 1. & Uluslararası Kuşadası Film Festivali \\
\hline
\end{tabular}

Tablo 4. Üniversiteler Tarafından Düzenlenen Uluslararası Film Festivalleri

\begin{tabular}{|l|l|l|}
\hline Yıl & Üniversiteler Tarafından Düzenlenen Uluslararası Film Festivalleri & Üniversite \\
\hline 18. & Uluslararası Eskişehir Film Festivali & Anadolu \\
\hline 16. & Kısaca Uluslararası Öğrenci Filmleri Festivali & Selçuk \\
\hline 12. & Uluslararası Kar Film Festivali & Erzurum \\
\hline 9. & Uluslararası İnönü Üniversitesi Kısa Film Festivali & İnönü \\
\hline 6. & Uluslararası Gençlik Filmleri Festivali & İstanbul \\
\hline 6. & Uluslararası Suç ve Ceza Film Festivali & İstanbul \\
\hline 3. & Uluslararası Contact Öğrenci Filmleri Festivali & Yaşar \\
\hline
\end{tabular}


Türkiye'de 2016 yılında üniversiteler tarafından düzenlenen uluslararası film festivali sayısı 7'dir (Tablo 4). Bunların 2'si kısa film festivalidir. Bu festivallerden en uzun süre düzenlenmiș olanı, Uluslararası Eskişehir Film Festivalidir. Anadolu Üniversitesi tarafından düzenlenen bu festival, 2016 yılında 18. kez izleyicisiyle buluşmuştur. Ardından Selçuk Üniversitesi tarafından 16 kez düzenlenmiş olan Kısaca Uluslararası Öğrenci Filmleri Festivali gelmektedir. Uluslararası Kar Film Festivali 12 kez, Uluslararası İnönü Üniversitesi Kisa Film Festivali 9 kez, Uluslararası Gençlik Filmleri Festivali 6 kez ve Uluslararası Suç ve Ceza Film Festivali 6 kez düzenlenmiştir. Bir üniversite tarafından düzenlenen en genç festival ise Yaşar Üniversitesi tarafından 2016 yılında 3. kez düzenlenmiş olan Uluslararası Contact Öğrenci Filmleri Festivalidir.

\section{Uluslararası Eskişehir Film Festivali}

Uluslararası Eskişehir Film Festivali, T.C. Kültür ve Turizm Bakanlığı’nın da desteği ile Anadolu Üniversitesi İletişim Bilimleri Fakültesi tarafından düzenlenmektedir. Festival komitesinin çoğunluğu, Sinema ve Televizyon Bölümü öğretim üyelerinden oluşmaktadır. Festival ilk kez 1998 yılında "Sinema Günleri” adı ile düzenlenmiştir. 2007 yılında Uluslararası Eskişehir Film Festivali adı ile düzenlenmiştir. 2016 yılının Mayıs ayında 18. kez izleyicisiyle buluşmuştur. Bu etkinlikte sinema ve televizyon bölümü öğrencileri, sinema camiasının paydaşları ile bir araya gelmektedir. Festival öğrencilerin iletişim ve sinema televizyon alanında kendilerini geliştirmeleri için zemin sunmaktadır. Film üretiminin senaryo, görüntü, oyuncu, ışık, kamera vb. birçok alanından akademik veya sektör deneyimine sahip Türkiye'den ve diğer ülkelerden gelen katılımcılar, bu alana ilgi duyan kişilere de atölye çalışmaları, söyleşiler ile hitap etmektedir. Halka açık olan Uluslararası Eskişehir Film Festivali öncelikle Anadolu Üniversitesi, ardından Eskişehir ve çevre illere yayılan bir halka içinde etkin olması fikri ve beklentisi ile düzenlenmektedir.

\section{Yöntem}

Bilet satış rakamları izleyici sayısını verdiği için bir önceki yıla ait Uluslararası Eskişehir Film Festivali bilet satış rakamları üzerinden araştırma evreni belirlenmiştir. Sekaran’nn (2003: 294) örnekleme çer- çevesinin ve örnek büyüklüğünün belirlenmesi için "belirli evrenler için kabul edilebilir örnek büyüklükleri” tablosundan yararlanılarak uygulanması gerekli anket sayısı belirlenmiş, 20 kişi ile ön testi yapılmış ve 250 festival katılımcısına anket uygulanarak izleyici profili tanımlanmaya çalışılmıştır.

\section{Bulgular ve Yorum}

\section{Demografik Veriler}

$\mathrm{Bu}$ bölümde festival katılımcısının cinsiyetini, yaşın1, gelir düzeyini ve öğrenim durumunu öğrenmek amacıyla sorulan sorulara ilişkin elde edilen bulgular yorumlanmaktadır.

\section{İzleyicinin Cinsiyeti}

Tablo 5. İzleyicinin Cinsiyeti

\begin{tabular}{|l|l|l|}
\hline İzleyicinin Cinsiyeti & Sıklık & Yüzde \\
\hline Kadın & 139 & 55,6 \\
\hline Erkek & 111 & 44,4 \\
\hline TOPLAM & 250 & 100 \\
\hline
\end{tabular}

Araştırmaya katılan festival izleyici kitlesinin tamamı cinsiyet sorusunu yanıtlamışlardır. Buna göre katılımcıların \%56'sı kadın iken, \%44'ü erkektir. Örneklemde, kadınların erkeklere oranla, \%12'lik bir farkla festivale daha fazla ilgi gösterdikleri anlaşılmaktadır.

\section{İzleyicinin yaşı}

Tablo 6. İzleyicinin Yaşı

\begin{tabular}{|c|c|c|}
\hline Doğum Tarihi (Yaş) & Sıklık & Yüzde \\
\hline $1990-1994(26-22)$ & 95 & 38 \\
\hline 1995-1999 (21-17) & 80 & 32 \\
\hline $1985-1989(31-27)$ & 25 & 10 \\
\hline 1980-1984 (36-32) & 14 & 5,6 \\
\hline $1970-1974(46-42)$ & 10 & 4 \\
\hline $1965-1969(51-47)$ & 8 & 3,2 \\
\hline 1975-1979 (41-37) & 7 & 2,8 \\
\hline 2000-2004 (16-12) & 7 & 2,8 \\
\hline $1955-1959(61-57)$ & 2 & 0,8 \\
\hline $1960-1964(56-52)$ & 2 & 0,8 \\
\hline TOPLAM & 250 & 100 \\
\hline
\end{tabular}

Araştırmaya katılan festival izleyici kitlesinin \%38'i 26-22 yaş grubundadır. Bu veri, izleyicilerin çoğunlukla gençlerden oluştuğunu göstermektedir. Bunu 
\%32 ile 21-17 yaş grubu izlerken, ardından \%10 ile 31-27 yaş arası izleyiciler gelmektedir. 37 yaş ve üzerindeki izleyicilerin toplam oranı $\% 12$ iken, $16-12$ yaş grubunun oranı $\% 3$ ’ür.

\section{Ĕ̆itim Durumu}

Tablo 7. İzleyicinin Eğitim Durumu

\begin{tabular}{|l|c|c|}
\hline Eğitim Durumu & Sıklık & Yüzde \\
\hline Lise & 160 & 64 \\
\hline Lisans & 37 & 14,8 \\
\hline Ortaokul & 19 & 7,6 \\
\hline Doktora & 17 & 6,8 \\
\hline Yüksek Lisans & 15 & 6 \\
\hline Okul bitirmemiş & 2 & 0,8 \\
\hline \multicolumn{1}{|c|}{ TOPLAM } & 250 & 100 \\
\hline
\end{tabular}

Araştırmaya katılan festival izleyici kitlesinin \%64'ünün en son bitirdiği eğitim/öğretim programının lise olduğu görülmektedir. Bu durumda söz konusu bu izleyicilerin ya önlisans/lisans öğrenimlerini sürdürdükleri ya da liseden sonra öğrenimlerine devam etmedikleri söylenebilir. Çalışmaya katılan festival izleyici kitlesinin $\% 15$ 'i ise bir lisans programindan mezundur. Ayrica izleyicilerin \%8'i orta okul eğitimi, \%7'si doktora, \%6'sı yüksek lisans öğrenimi görmüştür. Festival anket çalışmasına katılan izleyicilerden 2 kişi (\%1) herhangi bir eğitim/öğrenim almadığını belirtmiştir.

\section{İzleyicinin Mesleğ}

Tablo 8. İzleyicinin Meslek Durumu

\begin{tabular}{|l|c|c|}
\hline Meslek & Siklık & Yüzde \\
\hline Öğrenci & 188 & 75,2 \\
\hline Öğretim Üyesi & 25 & 10 \\
\hline Diğer & 16 & 6,4 \\
\hline Öğretmen & 5 & 2 \\
\hline Mühendis & 4 & 1,6 \\
\hline Emekli & 4 & 1,6 \\
\hline Memur & 3 & 1,2 \\
\hline Oyuncu & 1 & 0,4 \\
\hline Tasarımc1 & 1 & 0,4 \\
\hline Serbest & 1 & 0,4 \\
\hline Ressam & 1 & 0,4 \\
\hline İşletmeci & 1 & 0,4 \\
\hline TOPLAM & 250 & 100 \\
\hline
\end{tabular}

Araştırmaya katılan festival izleyici kitlesinin \%75’i öğrenci, \%10’u da öğretim üyesidir. Geri kalan meslek gruplarının toplam oranı ise \%15'tir. Bu mesleklerin öğretmen, mühendis, emekli, memur, oyuncu, tasarımcı, serbest, ressam ve işletmeci olduğu görülmüştür. Mesleğini "diğer" olarak belirtmiş olan izleyici oranı ise \%16'dır. Buna göre festival izleyici kitlesinin büyük bir bölümünü öğrenciler oluşturmaktadır.

\section{Gelir Durumu}

Tablo 9. Gelir Durumu

\begin{tabular}{|l|c|c|}
\hline \multicolumn{1}{|c|}{ Aylık Gelir } & Sıklı & Yüzde \\
\hline $501-1000$ & 86 & 34,4 \\
\hline $0-500$ & 50 & 20 \\
\hline $2501-$ üstü & 48 & 19,2 \\
\hline $1001-1500$ & 36 & 14,4 \\
\hline Yanıt yok & 16 & 6,4 \\
\hline 1501-2000 & 12 & 4,8 \\
\hline 2001-2500 & 2 & 0,8 \\
\hline TOPLAM & 250 & 100 \\
\hline
\end{tabular}

Araştırmaya katılan festival izleyici kitlesinin \%34'ü 501-1000 TL gelir grubundan, \%20'si de 0-500 TL gelir grubundandır. Festival izleyici anketinin yapıldığ 1 tarihte asgari ücret net 1300 TL'dir. Buna göre araştırmaya katılanların \%54'ünün gelir seviyesi, asgari ücret düzeyinin altındadır. Ancak bu grubun yüksek olmasının nedeni, araştırmaya katılan izleyici kitlesinin büyük kısmını öğrencilerin oluşturmasıdır. Katılımcıların \%14'ünün gelir seviyesi yaklaşık olarak asgari ücret düzeyinde iken, \%20'sinin geliri ise 2501 TL ve üzerindedir.

\section{Festival Katılımcısının Film İzleme Alışkanlığı}

Bu bölümde festival izleyicisinin sinemaya gitme alı̧skanlığ 1 ve festivalin son iki yılında izlediği film sayılarına ait veriler yorumlanmaktadır.

Araştırmaya katılan festival izleyici kitlesinin \%43'ünün ayda $1 \mathrm{kez}, \% 16$ 'sinın 3-4 ayda $1 \mathrm{kez} v$ $\% 5$ ’inin de yılda bir-iki kez sinemaya gittiği anlaşılmaktadır. Sinemaya haftada bir kez gidenlerin oranı $\% 14$, ayda birden fazla kez gidenlerin oran $\% 12$ 'dir. Haftada birden fazla kez sinemaya giden festival izleyicisinin oranı ise $\% 8$ 'dir. Bu durumda haftada en 
Tablo 10. Sinemaya Gitme Sıklığı

\begin{tabular}{|c|c|c|}
\hline Sinemaya Gitme Sıklığı & Sıklık & Yüzde \\
\hline Ayda 1 & 109 & 43,6 \\
\hline 3-4 Ayda 1 & 41 & 16,4 \\
\hline Haftada 1 & 35 & 14 \\
\hline Ayda 1'den Fazla & 30 & 12 \\
\hline Haftada 1'den Fazla & 20 & 8 \\
\hline Yilda 1-2 Defa & 13 & 5,2 \\
\hline Hiç Gitmedim & 2 & 0,8 \\
\hline TOPLAM & 250 & 100 \\
\hline
\end{tabular}

az bir kez sinemaya gidenler, araştırmaya katılanların \%22'sini oluşturmaktadır. Diğer bir deyişle, sinemaya gitmenin gündelik yaşamlarının bir parçası olanlar, araştırmaya katılan festival izleyicisinin 1/4’ünü oluşturmaktadır.

\section{Yılında Festivalde İzlediği Film Sayısı}

Araştırmaya katılan festival izleyici kitlesinin \%29'u, 2015 yllında düzenlenen Eskişehir Film Festivali’nde hiç film izlemediğini belirtmiştir. Diğer bir deyişle, 2016 yılında Uluslararası Eskişehir Film Festivali ile tanışan yeni bir kitle söz konusudur. 2015 yllındaki festivalde 3-4 film izleyenlerin oranı \%23, 5-10 film izleyenlerin oranı ise \%21'dir. 11'den fazla film izleyenlerin oran $1 \% 8$ iken, 1-2 film izleyenlerin oranı \%19'dur. Buna göre, 2016 yılında düzenlenen Eskişehir Film Festivali’ne katılan izleyici kitlesinin \%71'i 2015 yılında da festivale katılmıştır.

Tablo 11. Sinemaya Gitme Sıkığı

\begin{tabular}{|l|c|c|}
\hline \multicolumn{1}{|c|}{ 2015 Yılında Festivalde İzlediği Film Sayısı } & Sıklık & Yüzde \\
\hline Hiç İzlemedim & 73 & 29,2 \\
\hline 3-4 Film & 57 & 22,8 \\
\hline 5-10 Film & 53 & 21,2 \\
\hline 1-2 Film & 48 & 19,2 \\
\hline 11'den fazla TOPLAM & 19 & 7,6 \\
\hline \multicolumn{2}{|c|}{250} & 100 \\
\hline
\end{tabular}

\section{Yılında Festivalde İzlediği Film Sayısı}

Tablo 12.de görüldüğü üzere araştırmaya katılan festival izleyici kitlesinin \%44’ü, 2016 yllında düzenlenen Eskişehir Film Festivali’nde 4-7 film izlediğini belirtmiştir. Üçten az film izleyenlerin oranı ile 8-12 film izleyenlerin oranı birbirine eşittir. Festivalde 1320 film izleyenlerin oranı $\% 4,20$ den fazla film izleyenlerin oranı ise \%3'dir.

Tablo 12. İzleyicilerin 2016 Yılında Festivalde İzlediği Film Sayısı

\begin{tabular}{|l|c|c|}
\hline 2016 Yılında Festivalde İzlediği Film Sayısı & Sıklık & Yüzde \\
\hline 4-7 Film & 111 & 44,4 \\
\hline 3'ten az & 61 & 24,4 \\
\hline 8-12 Film & 61 & 24,4 \\
\hline 13-20 Film & 10 & 4 \\
\hline 20'den fazla TOPLAM & 7 & 2,8 \\
\hline \multicolumn{2}{|c|}{250} & 100 \\
\hline
\end{tabular}




\section{İzleyicilerin Bölüm Tercihleri ve Ölçütleri}

Bu bölümde araştırmaya katılan festival izleyici kitlesinin festivalde en çok tercih ettiği bölüm ile film tercih etme ölçütlerine dair verilere yer verilmiştir.

\section{Yılında Festivalde Birinci Sırada Tercih Edilen Bölüm}

Araştırmaya katılan festival izleyici kitlesinin ilk üç bölümden ilk tercihleri \%41'lik oranla "Dünya Festivallerinden" bölümü iken, ikinci tercihleri \%34 ile
“Türk Sineması 2015-16” bölümleri olduğu görülmektedir. "Sinema Tarihinin Unutulmazları" \%11'lik oranla üçüncü sırada yer alırken, "Gece Yarısı Sineması" \%4'lük oranla dördüncü sırada yer almaktadır. "Canlandırma Filmleri" ile "Kısa Filmler" yaklaşı \%3'lük bir oranla aynı sırada yer almaktadır. "Hayatımız Belgesel" \%2, "Dünya Sinemasının Genç Yıldızları" \%1, "Engelli Farkındalı" \%0,4 oranında tercih edilmiştir.

\section{Tablo 13. 2016 Yılında Festivalde Birinci Sırada Tercih Edilen Bölüm}

\begin{tabular}{|l|c|c|}
\hline Festivalde Tercih Edilen Birinci Bölüm & Sıklık & Yüzde \\
\hline Dünya Festivallerinden & 103 & 41,2 \\
\hline Türk Sineması 2015-16 & 84 & 33,6 \\
\hline Sinema Tarihinin Unutulmazları & 28 & 11,2 \\
\hline Gece Yarısı Sineması & 10 & 4 \\
\hline Canlandırma Filmleri & 7 & 2,8 \\
\hline Kısa Filmler & 7 & 2,8 \\
\hline Hayatımız Belgesel & 6 & 2,4 \\
\hline Dünya Sinemasının Genç Yıldızları & 3 & 1,2 \\
\hline Engelli Farkındalık & 1 & 0,4 \\
\hline Yanıt yok & 1 & 0,4 \\
\hline \multicolumn{1}{|c|}{ TOPLAM } & 250 & 100 \\
\hline
\end{tabular}

\section{Yılında Festivalde İkinci Sırada Tercih Edilen Bölüm}

Araştırmaya katılan festival izleyici kitlesinin ilk üç bölümden ikinci tercihlerinin başında \%25'lik bir oranla "Dünya Festivallerinden" bölümünün geldiği görülmektedir. İkinci sırada \%21 oranla "Sinema Ta- rihinin Unutulmazları", üçüncü sırada ise \%15 oranla "Türk Sineması 2015-16" bölümü gelmektedir. Bu siralamayı, "Gece Yarısı Sineması" \%11, "Hayatımız Belgesel" \%6, "Kisa Filmler" \%6, "Canlandirma Filmler" \%5 ve "Engelli Farkındalik" \%2 oranla takip etmektedir.

Tablo 14. 2016 Yılında Festivalde İkinci Sırada Tercih Edilen Bölüm

\begin{tabular}{|c|c|c|}
\hline Festivalde Tercih Edilen İkinci Bölüm & Sıklık & Yüzde \\
\hline Dünya Festivallerinden & 62 & 24,8 \\
\hline Sinema Tarihinin Unutulmazları & 52 & 20,8 \\
\hline Türk Sineması 2015-16 & 38 & 15,2 \\
\hline Gece Yarıs1 Sinemas1 & 27 & 10,8 \\
\hline Dünya Sinemasının Genç Yıldızları & 19 & 7,6 \\
\hline Hayatımız Belgesel & 16 & 6,4 \\
\hline Kisa Filmler & 15 & 6 \\
\hline Canlandırma Filmleri & 13 & 5,2 \\
\hline Engelli Farkındalık & 4 & 1,6 \\
\hline Yanit yok & 4 & 1,6 \\
\hline TOPLAM & 250 & 100 \\
\hline
\end{tabular}




\section{Yılında Festivalde Üçüncü Sırada Tercih Edilen Bölüm}

Araştırmaya katılan festival izleyici kitlesinin ilk üç bölümden üçüncü tercihlerine verdikleri cevapların başında \%21'lik bir oranla "Sinema Tarihinin Unutulmazlar»" bölümü olduğu görülmektedir. Ardından "Gece Yarısı Sineması" ve "Dünya Sinemasinın Genç Yıldızları" bölümleri \%15 oranla aynı sırada yer almaktadır. "Kısa Filmler" \%13 oranla dördüncü, "Dünya Festivallerinden" bölümü ise \%10 oranla beşinci sırada yer almaktadır. Bu sıralamayı "Türk Sinemast 2015-16" \%8, "Hayatımız Belgesel" \%7, "Engelli Farkındalik" \%5 ve "Canlandirma Filmler" \%3 oranla takip etmektedir. Araştırmaya katılanların \%3'ü bu soruya yanıt vermemiştir.

\section{Tablo 15. 2016 Yılında Festivalde Üçüncü Sırada Tercih Edilen Bölüm}

\begin{tabular}{|c|c|c|}
\hline Festivalde Tercih Edilen Üçüncü Bölüm & Sıklık & Yüzde \\
\hline Sinema Tarihinin Unutulmazları & 53 & 21,2 \\
\hline Gece Yarısı Sineması & 37 & 14,8 \\
\hline Dünya Sinemasının Genç Yıldızları & 37 & 14,8 \\
\hline Kisa Filmler & 33 & 13,2 \\
\hline Dünya Festivallerinden & 25 & 10 \\
\hline Türk Sineması 2015-16 & 19 & 7,6 \\
\hline Hayatımız Belgesel & 18 & 7,2 \\
\hline Engelli Farkındalık & 12 & 4,8 \\
\hline Canlandırma Filmleri & 8 & 3,2 \\
\hline Yanit yok & 8 & 3,2 \\
\hline TOPLAM & 250 & 100 \\
\hline
\end{tabular}

\section{Yılında Festivalde Film Tercihini Belirleyen Birinci Ölçüt}

Araştırmaya katılan festival izleyicisinin \%47'si festivalde film tercihini belirleyen birinci ölçütün " $\mathrm{Ko}$ nularına Göre" olduğunu belirtmişlerdir. İzleyicilerin ikinci ölçütü ise \%21'lik oranla "Yönetmenine Göre" film tercihi olurken, \%8'inin tercihini filmlerin “Türüne Göre" belirlemektedir. Ardından "Aldığı Ödüllere Göre" \%6, "Rastlantısal" \%6, "Festival Kitapçığına Göre" \%6, "Vizyonda Kaçırllan Filmler" \%2, "Eleștirmen Görüşüne Göre" \%2 ve "Ülkesine Göre" \%1’lik bir oran gelmektedir.

Tablo 16. 2016 Yılında Festivalde Film Tercihini Belirleyen Birinci Ölçüt

\begin{tabular}{|l|c|c|}
\hline Festivalde Film Tercihi Ölçütü & Sıklık & Yüzde \\
\hline Konularına Göre & 118 & 47,2 \\
\hline Yönetmenine Göre & 52 & 20,8 \\
\hline Türüne Göre & 21 & 8,4 \\
\hline Aldı̆̆ı̈ Ödüllere Göre & 15 & 6 \\
\hline Rastlantısal & 15 & 6 \\
\hline Festival Kitapçığına Göre & 14 & 5,6 \\
\hline Vizyonda Kaçırılan Filmler & 6 & 2,4 \\
\hline Eleştirmen Görüşüne Göre & 5 & 2 \\
\hline Ülkesine Göre & 3 & 1,2 \\
\hline Yanıt Yok TOPLAM & 1 & 0,4 \\
\hline & 250 & 100 \\
\hline
\end{tabular}


2016 Yılında Festivalde Film Tercihini Belirleyen İkinci Ölçüt

Araştırmaya katılan festival izleyici kitlesinin festivalde film tercihini belirleyen ikinci ölçüt, \%25'lik oranla "Yönetmenine Göre" yapılan film tercihidir. Festival izleyicisinin ikinci ölçütü \%21 oranla "Türüne Göre", üçüncü ölçütü ise \%16 oranla "Konularına Göre" film seçimidir. Dördüncü ölçüt \%11 oranla "Aldığı Ödüllere Göre" iken, bu soruya yanıt vermeyenlerin oranı \%6'dır. Film tercihini "Festival Kitapçı̆̆ına Göre" yapanların oranı \%5, "Ülkesine Göre" yapanların oranı \%5, "Vizyonda Kaçırılan Filmlere Göre" yapanların oranı \%3,2 ve "Rastlantısal" olarak yapanların oranının ise $\% 2$ olduğu görülmektedir.

Tablo 17. 2016 Yılında Festivalde Film Tercihini Belirleyen İkinci Ölçüt

\begin{tabular}{|c|c|c|}
\hline Festivalde Film Tercihi Ölçütü & Sıklık & Yüzde \\
\hline Yönetmenine Göre & 63 & 25,2 \\
\hline Türüne Göre & 52 & 20,8 \\
\hline Konularına Göre & 41 & 16,4 \\
\hline Aldığı Ödüllere Göre & 27 & 10,8 \\
\hline Eleştirmen Görüşlerine Göre & 15 & 6 \\
\hline Yanit Yok & 15 & 6 \\
\hline Festival Kitapçığına Göre & 13 & 5,2 \\
\hline Ülkesine Göre & 12 & 4,8 \\
\hline Vizyonda Kaçırılan Filmlere Göre & 8 & 3,2 \\
\hline Rastlantısal & 4 & 1,6 \\
\hline TOPLAM & 250 & 100 \\
\hline
\end{tabular}

\section{Yılında Festivalde Film Tercihini Belirleyen Üçüncü Ölçüt}

Araştırmaya katılan festival izleyicisi kitlesinin festivalde film tercihini belirleyen üçüncü ölçüt, \%18 oranla "Türüne Göre" yapılan film tercihidir. İkinci sırada \% 15 'lik oranla "Aldığ Ödüllere" göre film tercihi yapanlar yer alırken, \%12'lik oranla "Eleştirmen
Görüşlerine Göre” film tercihi yapan izleyiciler yer almaktadır. Bu soruya yanıt vermeyenlerin oranı ise yaklaşık olarak \%10'dur. Ardından "Festival Kitapçı̆̆ına Göre" ve "Konularına Göre" tercih yapanların oranı \%9, "Rastlantısal" bir şekilde tercih yapanların oranı ile "Ülkesine Göre" ve "Yönetmenine Göre" tercih yapanların oranı hemen hemen eşit düzeydedir.

Tablo 18. 2016 Yılında Festivalde Film Tercihini Belirleyen Üçüncü Ölçüt

\begin{tabular}{|l|c|c|}
\hline Festivalde Film Tercihi Ölçütü & Sıklık & Yüzde \\
\hline Türüne Göre & 46 & 18,4 \\
\hline Aldı̆̆ı Ödüllere Göre & 37 & 14,8 \\
\hline Eleștirmen Görüşlerine Göre & 29 & 11,6 \\
\hline Vizyonda Kaçırılan Filmler & 26 & 10,4 \\
\hline Yanıt Yok & 24 & 9,6 \\
\hline Festival Kitapçığına Göre & 22 & 8,8 \\
\hline Konularına Göre & 21 & 8,4 \\
\hline Rastlantısal & 16 & 6,4 \\
\hline Ülkesine Göre & 15 & 6 \\
\hline Yönetmenine Göre & 14 & 5,6 \\
\hline \multicolumn{1}{|c|}{ TOPLAM } & 250 & 100 \\
\hline
\end{tabular}




\section{Festivale Katılımın Nedenleri}

Birden fazla seçenek işaretleyebilecekleri belirtilen bu soruda yüzdelik değerler bu durum dikkate alınarak yorumlanmalıdır. Araştırmaya katılan festival izleyicisi kitlesinin \%61'i, festivale katılım nedenlerinin başında "Sanat Filmleri İzleyebilmek" olduğunu belirtmişlerdir. Festivale katılımın diğer ve aynı oranda nedenini "Ticari gösterime girme şansı olmayan filmleri izleyebilmek” olarak belirtmişlerdir. Katılımın bir diğer nedenini "Belli bir tür, konu veya yönetmenlerin birden fazla filmlerini izleyebilmek" diyenlerin oranı \%41, "Sinema tarihinin önemli yönetmen veya akımlarının toplu gösterimleri"ni gerekçe gösterin oranı ise \%40'tır. Festivale katılımını için "Panel ve söyleşi gibi etkinliklere katılarak sinema sanatın daha iyi anlamak" diyenlerin oran $1 \% 38$ ve son olarak "Diğer" nedenlerle festivale katılanların oranı \%12'dir.

Tablo 19. Festivale Katılım Nedenleri

\begin{tabular}{|l|c|c|}
\hline Festivale Katılma Nedenleri & Sıklık & Yüzde \\
\hline Sanat filmleri izleyebilmek & 153 & 61,2 \\
\hline Ticari gösterime girme şansı olmayan filmleri izleyebilmek & 153 & 61,2 \\
\hline Belli bir tür, konu veya yönetmenlerin birden fazla filmlerini izleyebilmek & 102 & 40,8 \\
\hline Sinema tarihinin önemli yönetmen veya akımlarının toplu gösterimleri & 99 & 39,6 \\
\hline Panel ve söyleşi gibi etkinliklere katılarak sinema sanatını daha iyi anlamak & 95 & 38 \\
\hline Diğer & 29 & 11,6 \\
\hline
\end{tabular}

\section{Sonuç}

Uluslararası Eskişehir Film Festivali özelinde izleyici profilini tanımlamaya yönelik bu çalışmanın demografik verileri değerlendirildiğinde; Uluslararası Eskişehir Film Festivali izleyici kitlesinin \%70’i, 17-26 yaş grubunda olduğu belirlenmiştir. \%91'i lise ve üzeri eğitim seviyesine sahiptir. Çoğunluğunu üniversite öğrencileri (\%75) ve bir meslek sahibi kişiler (\%18) oluşturmaktadır. Öte yandan, çoğunluğun gelir seviyesi (\%54) asgari ücret düzeyinin altındadır. Gelir düzeyinin bu durumu, izleyici kitlesinin \%70'nin öğrencilerden oluşması ile açıklanabilmektedir.

Festival izleyici kitlesinin \%78'i, ayda birden fazla kez sinemaya gitmektedir. Bu durum festival izleyicisinin sinemaya gitme alışkanlığının gündelik yaşamlarının bir parçası olduğu anlamını taşımaktadır. Eskişehir Film Festivali'ne katılan izleyici kitlesinin \%71'i bir önceki yıl da festival katılanlardan oluşmaktadır. Festival izleyicisinin çoğunluğunun (\%76) festival kapsamında 42'ten fazla film izlediği bulgulanmıştır. İzleyicilerin öncelikli tercihi (\%41) "Dünya Festivallerinden" bölümü, ikinci tercihi (\%34) "Türk Sineması 2015-16" olurken, "Sinema Tarihinin Unutulmazla$r \imath$ ” bölümü, üçüncü (\%11) sırada yer almıștır. Film tercihleri belirleyen ölçütler ise "Konularına Göre" (\%47), "Yönetmenine Göre" (\%21), "Türüne Göre" (\%8) cevapları ağırlık kazanmıştır.
Festivale katılım nedenleri sorulan izleyiciler, aynı oranlarda (\%61) "Sanat Filmleri İzleyebilmek" ve "Ticari gösterime girme şansı olmayan filmleri izleyebilmek” olarak belirtmişlerdir. Bu oranın yüksek olmasının nedeni, alan yazında da belirtildiği üzere, festivaller dışında bu filmlere ulaşmanın zorluğu ile ilgilidir. Çünkü bu tür filmler uluslararası pazarda dağıtım ve gösterim ağına girme olanağı bulamamaktadır. Bu nedenle bu tür filmlerin, festivaller aracılığıyla izleyicisiyle buluşabiliyor olması Eskişehir film festivali izleyicisi tarafından da anlaşılarak sunulan fırsatlar değer bulmuştur. Öte yandan, İzleyici kitlesinin gençlerle sınırlı kültürel bir kaynak olduğu, filmler ve yönetmenler ve atölye çalışmaları bakımından uluslararası katılımcılarının olduğu ancak başka ülkelerden festival takip etmek üzere izleyici olarak gelen katılımcısının bulunmadığının da gözlemlendiğini belirtmek gerekmektedir. Bu durum küresel film festival ağının bir parçası olmamış olmakla ilişkilendirilebilir.

$\mathrm{Bu}$ oranın yüksek olmasının nedeni, alan yazında da belirtildiği üzere, festivaller dişında bu filmlere ulaşmanın zorluğudur. Çünkü bu tür filmler uluslararası pazarda, dağıtım ve gösterim ağına girme olanağ bulamamaktadır. Festivaller bu tür filmlerin izleyiciyle buluşmasında bir köprü işlevi görmektedir. Bu durum, Eskişehir Film Festivali'nde "Sanat Filmleri 
İzleyebilmek" ve "Ticari Gösterime Girme Şansı Olmayan Filmleri İzleyebilmek" oranının yüksek olmasının nedenini açıklamaktadır.

Son olarak araştırma bulgularına göre, Türkiye'de düzenlenen hem ulusal hem de uluslararası film festivali organizasyonlarının sayısı her yil artmaktadır. Türkiye'de 2016 yılında düzenlenmiş olan film festivali sayısı 81'dir. Bu festivallerin $44^{\prime}$ ü uluslararası film festivali, 37'si ulusal film festivali niteliğindedir. Ancak film festivalleri ve izleyici kitleleri ile ilgili çalışmaların, alanı tanımlayacak kadar kapsamlı ve yeterli olmadığı görülmüştür. Çünkü bu çalışmanın Türkiye'de düzenlenen festivallerle ilgili tablolarında da görüleceği üzere "ulusal", "uluslararası" ya da "film/ sinema günleri" gibi, bir festivalin kapsamını belirleyen bu nitelendirmelerin, hangi ölçütlere göre kullanılması gerektiği ile ilgili bir konsensüsün olmadığı anlaşılmaktadır. Bu alanda yapılacak çalışmalara ve düzenlemelere de ihtiyaç olduğu anlaşılmaktadır.

\section{Kaynakça}

Akari, N. (2016). Türk sinemasında kadının temsilinde alternatif bir mecra olarak uluslararası gezici FILMMOR kadın filmleri festivali. (Yayımlanmamış Yüksek Lisans Tezi). Maltepe Üniversitesi/Sosyal Bilimler Enstitüsü, İstanbul.

Altıntaş, V. (2009). Antalya Golden Orange Film Festival Impacts on the Local Community. Event Management and Sustainability. Ed. RazaqRaj and James Musgrave.Uk: MPG Books Group.

Altunışık, R., Coşkun, R., Bayraktaroğlu, S., Yıldırım, E., (2010). Sosyal Bilimlerde Araştırma Yöntemleri /SPSS Uygulamal. Adapazarı: Sakarya Yayıncilık.

Batık, E. (2008). Uluslararası film festivalleri ve sömürgeciliğin yerel formları. (Yayımlanmamış Yüksek Lisans Tezi). Ankara: Orta Doğu Teknik Üniversitesi.

Chhabra, D. (2001). Heritage Tourism: An Analysis of Perceived Authenticity and Economic Impact of the Scottish Highland Games in North Caroline. (Doctorate Thesis: Um1.3030030). North Caroline State University, Department Of Forestry, USA.
Çakır, M. (2009). Festival Turizmi. http://m-cakir. blogspot.com/2009/02/festival-turizmi_04.html, 21.02.2012.

Çelik, R. (2014). Film Festivalleri ve Türkiye'de Sinemanın Geleceği. İstanbul: Uluslararası Boğaziçi Sinema Derneği.

Çulha, O. (2008). Kültür Turizmi Kapsamında Destekleyici Turistik Ürün Olarak Deve Güreşi Festivalleri Üzerine Bir Alan Çalışması. Journal of Yasar University. 3 (12), 1827-1852.

De Bres, K., Davis, J. (2001). Celebrating Group and Place Identity: A Case Study of a New Regional Festival Article in Tourism Geographies.3(3):326337. DOI: $10.1080 / 14616680110055439$.

Duffy, M. (2005). Performing Identity Within a Multicultural Framework. Social and Cultural Geography. 6 (5), $677-692$.

Eagles, P. F. J., McCool, S. F., Haynes, C. D. A. (2002). Sustainable Tourism in Protected Areas: Guidelines for Planning and Management. Cambridge: IUCN.

Ekin, Yakın (2011). Etkinlik Turizmi Kapsamında Festivaller ve Antalya Altn Portakal Film Festivalinin Yerel Halk Üzerindeki Sosyal Etkileri Konulu Bir Araştırma. (Yayımlanmamış Doktora Tezi). Akdeniz Üniversitesi/Sosyal Bilimler Enstitüsü, Antalya.

Elkatmış, E. (2015). Film Festivalleri ve Türkiyede Sinemanın Geleceği. İstanbul: Uluslararası Boğaziçi Sinema Derneği.

Erkılıç, H. (2009). Düş Şatolarından Çoklu Salonlara Değişen Seyir Kültürü ve Sinema. Kebikeç, 27, 143162.

Evans, O. (2007). Border Exchanges: The Role of The European Film Festival. Journal of Contemporary European Studies. 15 (1), 23-33.

Film Ekibi (2006). Giovanni Scgonamillo ile Antalya Film Festivali Üzerine. Yeni Film, 12, 56-60. 
Frohlick, S. (2005). That Playfulness of White Masculinity: Mediating Masculinities And Adventure At Mountain Film Festivals. Tourist Studies, 5 (2),175193.

Frost, W. (2008). Projecting An Image: Film-Induced Festivals in The American West. Event Management, 12 (2), 95-103.

Gamson, J. (1996). The Organizational Shaping Of Collective İdentity: The Case Of Lesbian And Gay Film Festivals in New York. Sociological Forum, 11 (2), 231-261.

Getz, D. (2010). The Nature and Scope of Festival Studies. International Journal of Event Management Research, 5(1), 1-47.

Giritlioğlu, İ., Avcıkurt, C. (2010). Şehirlerin Turistik Bir Ürün Olarak Pazarlanması, Örnek Şehirler ve Türkiyedeki Şehirler Üzerine Öneriler (Derlemeden Oluşmuş Bir Uygulama). Adıyaman Üniversitesi Sosyal Bilimler Enstitüsü Dergisi, 2010(4), 7489.

Giritlioğlu, İ., Olcay, A., Özekici, Y. K. (2015). Bir Turizm Çeşitliliği Olarak Festival Etkinliklerinin Sınıflandırılması: Türkiye Üzerine Bir Değerlendirme. Sosyal Bilimler Araştırmaları Dergisi, 13, 326-323.

Grunwell, S., Ha, I. (2008). Film festivals: An Empirical Study of Factors For Success. Event Management, 11 (4), 201-210.

Güçhan, G. (1993). Sinema-Toplum İlişkileri. Kurgu, 12, 51-71.Eskişehir: Anadolu Üniversitesi yay.

Gül, K., Erdem, B., Gül, M. (2013). Yerel Festivallerin Etkinliğine Bağlı Ziyaretçi Kazanımları: Sındırg1 Yağcıbedir Festivali Örneği. Süleyman Demirel Üniversitesi İktisadi ve İdari Bilimler Fakültesi Dergisi, 18 (2), 213-239.

Gürsoy, D., Kim, K., Uysal, M. (2004). Perceived Impacts of Festivals and Special Events by Organizers: An Extension and Validation. Tourism Management, 25, 171-181.
Hauser, A. (1984). Sanatın Toplumsal Tarihi, çev: Yıldız Gölönü, Istanbul: Remzi Kitabevi.

Houghton, Meg (2001). The Propensity of Wine Festivals to Encourage Subsequent Winery Visitation. International Journal of Wine Marketing, 13 (3), $32-41$.

International Federation of Film Producers Associations-FIAPF. erişimhttp://www.fiapf.org/intfilmfestivals_accreditation_2016.asp)

Jarvie, I.C. (1993). Sosyal Bir Kurum Olarak Sinemaya Gitme. Gülseren Güçhan (Çev.). 25.Kare. 5, 22-25.

Kellner, D. (2004). Culture Industries. Toby Miller ve Robert Stam (Ed.), A Companion to Film Theory içinde (s. 202-220). Oxford: Blackwell Publishing.

Kırel, S. (2006). Küresel Seyircilik, Hollywood ve "Öteki” Sinemalar Bağlamında İran Filmlerinin Konumlandırılması. Galatasaray Üniversitesi İletişim Dergisi, 2006 (4), 51-69.

Kim, J., Hong, S. (2007). Queer Cultural Movements and Local Counterpublics of Sexuality: A Case of Seoul Queer Films and Videos Festival. Inter-Asia Cultural Studies, 8 (4), 617-633.

Küçük, M. (2013). Kültür Turizmi Kapsamında Yer Alan Festival Etkinliklerinin Yerel Kalkınmaya Katkısı: Uluslararası Beyşehir Göl Festivali Üzerine Bir Araştırma. I. KOP Bölgesel Kalkınma Sempozyumu Bildiriler Kitabı içinde (s. 345-357). Konya.

Litvin, S. W., Fetter, E. (2006). Can a Festival Be Too Successful? A Review of Spoleto, USA. International Journal of Contemporary Hospitality Management, 18 (1), $41-49$.

Malatya Film Festivali. erişim http://www.malatya.gov. tr/7-uluslararasi-malatya-film-festivali-ileri-birtarihe-ertelenmistir

McKercher, B., Mei, W. S., Tse, T. (2006). Are Short Duration Cultural Festivals Tourist Attractions? Journal of Sustainable Tourism, 14(1), 55-66. 
Onat, F., Gülay, G. (2015). İnternetin Sanat Festivallerinde Halkla İlişkiler Amaçlı Kullanımı: 20. ve 21. İzmir Avrupa Caz Festivalleri İzleyici Araştırması. Selçuk Üniversitesi İletişim Fakültesi Akademik Dergisi, 8(4), 49-72.

Öcal, L. H. (2013). Film Festivalleri ve Anlatı. (Yayımlanmamış Doktora Tezi). Marmara Üniversitesi/ Sosyal Bilimler Enstitüsü, İstanbul.

Özdemir, G. (2008). Destinasyon Pazarlaması. Ankara: Detay Yayıncilık.

Özkaracalar, K. (2015). Festivaller ve Kayıt Tescil Belgesi Sorunu. Yeni Film, 37-38, 59-66.

Öztürk, Z. (2003). 1923-50 Yılları Arasında Türk Sineması ve İstanbul. Deniz Bayrakdar (Ed.), Türk Film Araştırmalarında Yeni Yönelimler 3 içinde (59-67) İstanbul: Bağlam Yayınları.

Özyurt, O. (2014). Film Festivalleri ve Türkiye'de Sinemanın Geleceği. erişim http://www.bogazicifilmfestivali.com/wp-content/uploads/2015/11/ F\%C4\%B0LM-FEST\%C4\%B0VALLER\%C4\%B0-VEt\%C3\%BCRK\%C4\%BOYEDE-S\%C4\%B0NEMANINGELECE\%C4\%9E\%C4\%B0.pdf

Pios, K., Skoczylas, K., Wojckk, T. (2014). The Current Condition and Possibilities of Development of Festival Tourism in The Lublin Region. Sport Tourism, 21, 119-126.

Polat, S., Aktaş, S., Halis, M. (2013). Kent Kimliği Kapsamında Festivallerin Değerlendirilmesi: Uluslararası Altın Safran Film Festivali Örneği. Turizm ve Araştırma - TURßAR, 1(2), 14-25.

Pragay, G., Hosany, S., Nunkoo, R., Alders, T. (2013). London Residents' Support For The 2012 Olympic Games: The Mediating Effect of Overall Attitude. Tourism Management, 36, 629-640.

Qi, Y., Hanquin, Z., Mimi, L. (2012). Programing Quality of Festivals: Conceptualization, Measurement, and Relation to Consequences. International Journal of Contemporary Hospitality Management, 24 (4), 653-673.
Özarslan, Z. (2015). Sinema Kuramlar1-1. İstanbul: Su Yayınları.

Sekaran, U. 2003. Research Methods For Business. ABD: Southern Illinois University at Carbondale.

Sinema Genel Müdürlüğü. http://www.sinema.gov.tr/ TR,144750/turkiyede-sinema.html, 18.01.2017

Şengül, S., Genç, K. (2016). Festival Turizmi Kapsaminda Yöresel Mutfak Kültürünün Destekleyici Ürün Olarak Kullanılmasi: Mudurnu İpekyolu Kültür Sanat Ve Turizm Festivali Örneği. Pamukkale Üniversitesi Sosyal Bilimler Enstitüsü Dergisi, 23, 79-89.

Türk Akreditasyon Kurumu-TÜRKAK. erişim http:// www.turkak.org.tr/turkaksite/akreditasyonakreditasyonnedir.aspx

Uğurlu, H., Uğurlu, E. G. (2011). Uluslararası Eskişehir Film Festivali İzleyici Araştırması. Anadolu University Journal of Social Sciences, 11(3), 259-276.

Uzunkaya, E. (2009). Türkiye’nin Uluslararası Platformlardaki Tanıtım Faaliyetleri İçinde Halk Oyunları Festivallerinin Rolü. Akademik Bakış,16. erişim http://www.akademikbakis.org/ eskisite/16/15oyun.pdf

Wallin, M. R., Collins, B., Hull, J. S. (2013). It's Not Just About the Film: Festivals, Sustainability, and Small Cities. Tomas Pernecky, Michael Lück (Ed.), Events, Society and Sustainability: Critical and Contemporary Approaches içinde (229-243). London: Routledge.

Ylldırım, B. (1990). Uluslararası film festivalleri kapsamında Türk sineması. (Yayımlanmamış Yüksek Lisans Tezi). İstanbul Üniversitesi/Sosyal Bilimler Enstitüsü, İstanbul.

Yıldız, S. B., Polat, E. (2016). Yerel Halkın Eskişehirde Düzenlenen Festivallerin Etkilerine Yönelik Alg1lar1. Local. Journal of Tourism and Gastronomy Studies, 40, 62 . 